The definitive version is available at http://onlinelibrary.wiley.com/

\title{
Influence of finish treatment on the durability of aramid fibers aged under an alkaline environment
}

\author{
Guillaume Derombise $^{1}$, Laëtitia Vouyovitch Van Schoors ${ }^{1,{ }^{*}}$, Marie-Fleur Messou ${ }^{1}$, Peter Davies ${ }^{2}$ \\ ${ }^{1}$ Division for Material Physicochemistry, Laboratoire Central des Ponts et Chaussées, Paris, France \\ ${ }^{2}$ Testing and Technology Research Department, IFREMER (French ocean institute), Brest, France \\ *: Corresponding author : Laëtitia Vouyovitch Van Schoors, email address : laetitia.van-schoors@lcpc.fr
}

\begin{abstract}
:
Aramid fibers are high-performance materials which have been used in ropes and protective clothing for many years. They are also now being proposed in geotextiles for ground reinforcement. The influence of the surface finish composition and content has been studied in the field of cables and textiles, but there is no published data concerning the effect of a finish treatment on the hydrolytic degradation. Aramid fibers with different finish contents have been aged in an alkaline environment. The degradation has been identified by FTIR, viscosimetry, TGA, SEM, and tensile tests. For Technora fibers, the presence of finish appears to limit the tensile strength loss of aramid fibers at $\mathrm{pH}$ 11 by limiting abrasion, as well as bulk and surface degradation. For Twaron fibers, higher finish content only has a slight influence on the fibers durability at $\mathrm{pH} 11$ and $\mathrm{pH}$ 9, by limiting abrasion and bulk degradation.
\end{abstract}

Keywords: aramids, fibres, aging, finish, hydrolysis 


\section{Introduction}

A few years ago, geotextiles based on polyethylene terephtalate fibres were commonly used for alkaline ground reinforcement applications. However, when they were observed to display premature aging under these conditions (lime, cement or slag treated soils, next to the skin of hardened concrete, etc.), ${ }^{1}$ alternative solutions were developed, among which are geotextiles made of aramid fibres. $^{2,3}$ Two types of aramid material are considered here: Twaron fibres, based on poly $(p$ phenylene terephtalamide) (PPTA) similar to Kevlar fibres, and Technora fibres, based on copoly(paraphenylene/3,4'-oxydiphenylene terephtalamide) (Figure 1).
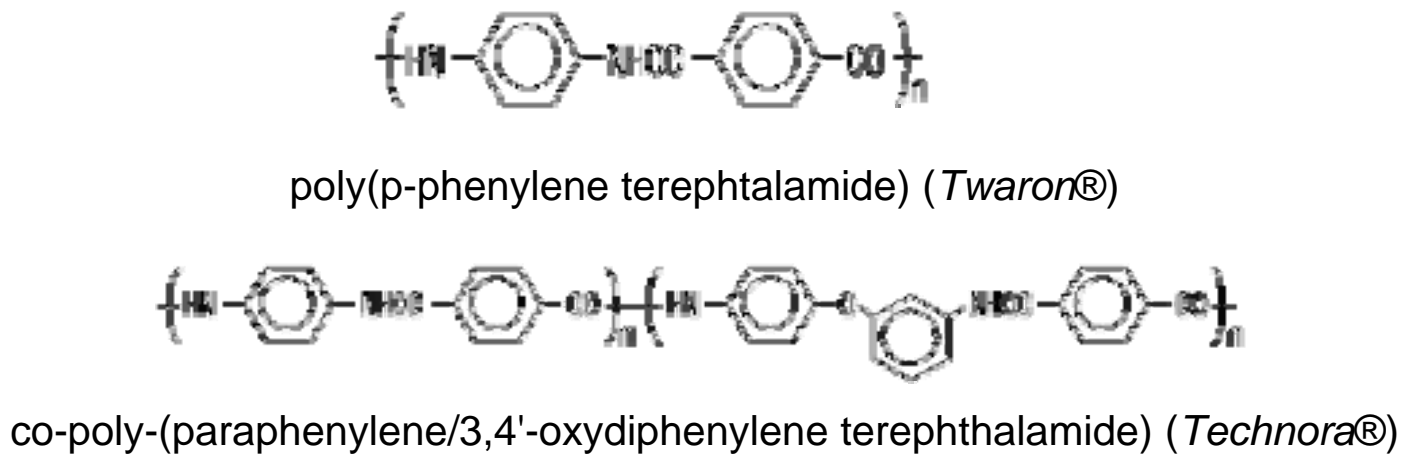

Figure 1: Aramid molecular structures

Twaron and Technora fibres both contain amide functions that are sensitive to hydrolysis; ${ }^{4,5}$ although, Imuro and Yoshida ${ }^{6}$ reported that the dilution of aramid-linkages by ether-linkages as in Technora fibres may contribute to provide the latter with better hydrolytic stability. The mechanism of PPTA hydrolysis has been identified and involves scission of the amide $\mathrm{N}-\mathrm{C}$ linkage, yielding acid and amine functions $\mathbf{s}^{4,5}$ (Figure 2).

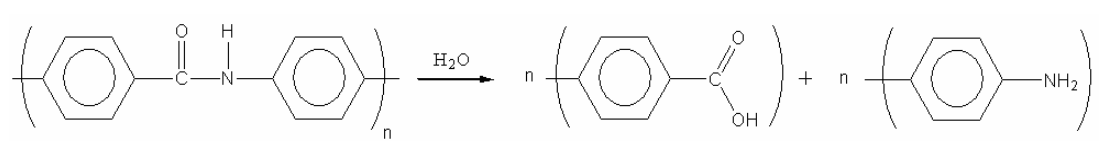

Figure 2: Hydrolysis of PPTA

Springer et al. ${ }^{7}$ evaluated the influence of basic and acid hydrolytic treatments on the mechanical properties of PPTA fibres. They showed that both modulus and tensile strength were affected, but the property drops were larger in acid and basic solutions than in a neutral environment.

The processing of polymeric fibres generally includes a finish application step in order to improve their durability, performance and/or processability. The finish formulations are varied and depend on the applications: they can be composed of lubricants (to prevent yarn abrasion), antistatics (to avoid yarn decohesion and facilitate their winding), emulsifiers, anti-oxidants, anti-microbial additives, etc. ${ }^{8}$ The influence of the finish composition and content on the bending fatigue life of cables ${ }^{9}$ and on the processing of non-woven fabrics ${ }^{10}$ have been studied. For instance, Moraes D'Almeida et al. ${ }^{9}$ showed the bending fatigue life of Kevlar 29 braids is improved by a factor of four after impregnation in a polyurethane resin (4 wt\%) that limits internal abrasion. In a similar way, Wagner and Ahles ${ }^{10}$ highlighted that the addition of an antistatic and lubrication oil overlaid on Kevlar fibres improves the processing of non-woven fabrics. However the influence of the finish on the hydrolytic degradation of aramid fibres has not been discussed in detail previously.

In the present paper, the degradation of Twaron and Technora fibres with different finish contents in an alkaline environment has been evaluated and correlated with mechanical properties. 


\section{Experimental}

\section{Materials}

Two kinds of aramid fibres have been studied in this paper: Twaron and Technora fibres, both produced by Teijin Aramid. The Twaron 1000 and Twaron 1010, in the form of 1680 dtex yarn, are based on the same polymer but have different finish contents: respectively 0.6-1 wt\% and 0.14 wt\%. In a similar way, Technora T240 and Technora T000 fibres, in the form of 1670 dtex yarns, are based on the same polymer but Technora T240 has $2.5 \mathrm{wt} \%$ of finish whereas Technora T000 is finish free.

\section{Aging methods}

Yarn samples were immersed in buffer sodium carbonate salt solutions at $\mathrm{pH} 9$ and $\mathrm{pH} 11$ up to one year aging. Two temperatures have been considered for each aging condition: 20 and $80^{\circ} \mathrm{C}$. Over the aging period considered here the temperature variability is estimated at $\pm 2{ }^{\circ} \mathrm{C}$.

\section{Analysis and characterization}

FTIR was performed in Attenuated Total Reflectance mode (ATR) mode with a Nicolet impact 410 spectrometer and Durascope Diamond ATR equipment. The spectra were recorded with a resolution of $2 \mathrm{~cm}^{-1}$, and an accumulation of 32 spectra. The spectra were analyzed with OMNIC 3.1 software. Each scan was made on a yarn, composed of 1000 filaments, and repeated three times per sample and condition.

Viscosity measurements were carried out using an Ubbelohde DIN (Schott Instruments) capillary viscosimeter, at $25^{\circ} \mathrm{C}$. For Twaron fibres, the weight average molecular mass was calculated from the Mark-Houwink relationship established by Arpin and Strazielle ${ }^{11}: \eta=8 \times 10^{-3} \mathrm{M}^{1.09}$. For that purpose, four concentrations between $5 \times 10^{-4} \mathrm{~g} / \mathrm{mL}$ and $2 \times 10^{-3} \mathrm{~g} / \mathrm{mL}$ were chosen. The reduced viscosity comparisons were performed at $2 \times 10^{-3} \mathrm{~g} / \mathrm{mL}$. The fibres were beforehand dissolved in $50 \mathrm{~mL}$ of sulphuric acid concentrated at $96 \%$ for two hours at $60^{\circ} \mathrm{C}$ with magnetic stirring. Above this dissolution temperature, additional degradation can occur in sulphuric acid. ${ }^{12}$ For Technora fibres, the reduced viscosities measurements were conducted from three concentrations between $3 \times 10^{-4} \mathrm{~g} / \mathrm{mL}$ and $1.5 \times 10^{-3} \mathrm{~g} / \mathrm{mL}$. The fibres were dissolved in $50 \mathrm{~mL}$ of sulphuric acid concentrated at $96 \%$ for two hours at $60^{\circ} \mathrm{C}$ with magnetic stirring. Because of the presence of ether linkages, Technora fibres are more susceptible to strong acid exposure than are pure aramid Twaron fibres. ${ }^{13}$ The remaining insoluble fractions after dissolution were extracted and weighed to calculate the true concentration of the solution.

Thermogravimetry Analysis (TGA) continuously measures the mass of a sample subjected to a steady increase of temperature. The thermal analyser used is a Netzsch STA 409 E. The data are processed with Proteus Analysis software. The temperature of the furnace was programmed to rise at constant heating rate of $10^{\circ} \mathrm{C} / \mathrm{min}$ up to $1150^{\circ} \mathrm{C}$. The tests were performed under a synthetic air flow of $80 \mathrm{~mL} / \mathrm{min}$. For each test, $\sim 25 \mathrm{mg}$ of material was weighed and stored in the same temperature and relative humidity controlled conditions before analysis.

Scanning electron micrographs of the fibres were performed to detect potential surface defects induced by aging. The pictures were taken with a Philips XL30 Scanning Electron Microscope in the Secondary Electron (SE) mode, in order to observe the surface topography, at $12 \mathrm{kV}$ voltage and a working distance of $10 \mathrm{~mm}$.

Tensile tests were performed on single fibres using a Zwick 1474 tensile testing machine with a $5 \mathrm{~N}$ load cell and a rate of extension of $\sim 10 \% / \mathrm{min}$ at $20^{\circ} \mathrm{C}$. Similar conditions have been chosen in previous studies. ${ }^{14,15}$ The fibre diameter was measured before each test using a laser micrometer Mitutoyo LSM-500S mounted on the tensile testing machine. The precision of the laser micrometer is $\pm 0.1 \mu \mathrm{m}$. Around fifteen valid measurements were considered for each condition and duration of aging. A measurement is considered as valid whenever the tensile fracture does not occur near the clamps. The tensile modulus was calculated between 0.3 and $0.6 \%$ elongation. 


\section{Results and discussion}

\section{Influence of the finish on the surface degradation}

\section{Twaron fibres}

The evolution of the normalised intensity of the peaks related to the finish and amide functions have been followed by Fourier Transformed Infrared (FTIR) in order to evaluate the surface hydrolysis of Twaron fibres with different initial finish contents. An infrared spectrum of Twaron 1000 as-received fibres is shown in Figure 3.

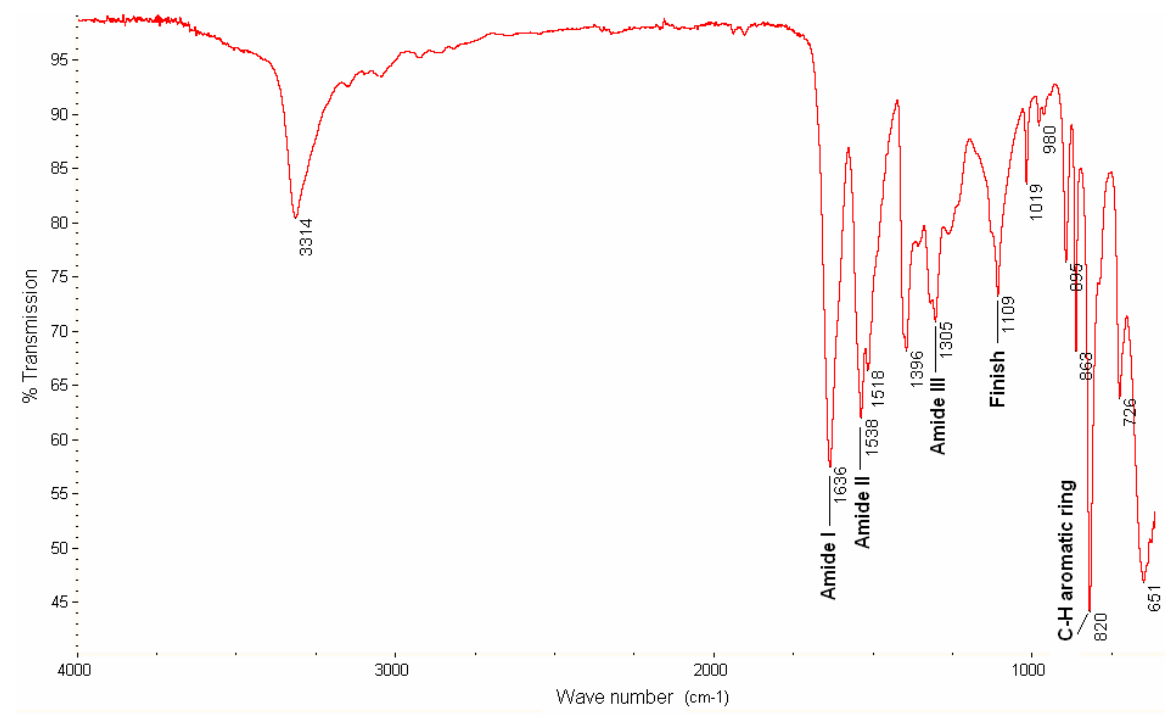

Figure 3: FTIR spectrum of as-received Twaron 1000 fibres

In order to perform semi-quantitative analysis, the peaks were normalised using the peak located at $\sim 820 \mathrm{~cm}^{-1}$ assigned to the $\mathrm{C}-\mathrm{H}$ deformation of aromatic rings, for which the intensity appears to be constant throughout the aging duration. The intensity of the peak located at $1109 \mathrm{~cm}^{-1}$ has been shown depend on the finish content: it is significantly larger for Twaron 1000 fibres (0.6-1 wt\% of finish) than for Twaron 1010 fibres (0.14 wt $\%$ of finish). This peak has been thus attributed to the finish. The amide function peaks have been identified as follows: the first peak located at $-1636 \mathrm{~cm}^{-1}$ is related to the $\mathrm{C}=\mathrm{O}$ vibration (amide I), the second at $\sim 1538 \mathrm{~cm}^{-1}$ is related to the combined motion of $\mathrm{N}-\mathrm{H}$ bending and $\mathrm{C}-\mathrm{N}$ (amide II), and the last at $1305 \mathrm{~cm}^{-1}$ is related to the $\mathrm{C}-\mathrm{N}, \mathrm{N}-\mathrm{H}$ and $\mathrm{C}-\mathrm{C}$ combined vibrations (amide III). ${ }^{16-18}$

Table 1 groups the normalised intensity of the peaks related to the finish and to the amide functions (amide I at $1636 \mathrm{~cm}^{-1}$ ) for Twaron 1000 and Twaron 1010 fibres after one year aging at $\mathrm{pH} 11$ and $\mathrm{pH} 9$. The normalised intensity of a peak is a ratio, expressed in \%, between the intensity of this peak and the intensity of an invariant peak (in our case the peak located at $\sim 820 \mathrm{~cm}^{-1}$ ).

Table 1: Normalized intensity of the peaks related to the amide I and finish of Twaron fibres asreceived and after one year 


\begin{tabular}{|c|c|c|c|c|c|}
\hline & & \multicolumn{2}{|c|}{$\begin{array}{c}\text { Twaron } 1010 \\
\text { (0.14 wt\% of finish) }\end{array}$} & \multicolumn{2}{|c|}{$\begin{array}{c}\text { Twaron } 1000 \\
\text { (0.6-1 wt\% of finish) }\end{array}$} \\
\hline & & Amide I & Finish & Amide I & Finish \\
\hline \multicolumn{2}{|c|}{ As-received } & $100 \pm 0.5$ & $100 \pm 2.8$ & $100 \pm 1.7$ & $100 \pm 4.5$ \\
\hline \multirow[t]{2}{*}{$\mathrm{pH} 11$} & $80^{\circ} \mathrm{C}$ & $98.6 \pm 1.7$ & $91.8 \pm 1.3$ & $96.2 \pm 0.9$ & $85 \pm 0.1$ \\
\hline & $20^{\circ} \mathrm{C}$ & $98.4 \pm 2.6$ & $94.9 \pm 1.1$ & $96.7 \pm 1.6$ & $87.7 \pm 0.8$ \\
\hline \multirow[t]{2}{*}{$\mathrm{pH} 9$} & $80^{\circ} \mathrm{C}$ & $96.8 \pm 1.7$ & $87.8 \pm 1.5$ & $96.1 \pm 0.4$ & $81.4 \pm 0.3$ \\
\hline & $20^{\circ} \mathrm{C}$ & $98.5 \pm 1.2$ & $91.7 \pm 2.5$ & $97.1 \pm 3.2$ & $81.1 \pm 2.6$ \\
\hline
\end{tabular}

It appears that the finish removal does not depend strongly on the temperature. However, the $\mathrm{pH}$ seems to affect it to a higher extent: the more the solution is basic, the lower the finish loss. This result indicates that the presence of $\mathrm{Na}_{2} \mathrm{CO}_{3}$ in the solution may form a "protective layer" at the surface of the fibres that would limit the finish removal. As for the chains degradation, the decrease in the peak related to amide functions appears to depend neither on the temperature nor on the $\mathrm{pH}$. The hydrolysis rates noted here are relatively low (between 1 and 4\% decrease) and similar for Twaron 1000 and Twaron 1010 fibres. Thus, the finish content does not have any influence on the surface hydrolysis of Twaron fibres.

\section{Technora fibres}

In a similar way, the evolution of the normalised intensity of the peaks related to the finish and amide functions have been followed in order to evaluate the surface hydrolysis of Technora fibres with or without initial finish contents. An infrared spectrum of Technora T240 as-received fibres is shown in Figure 4.

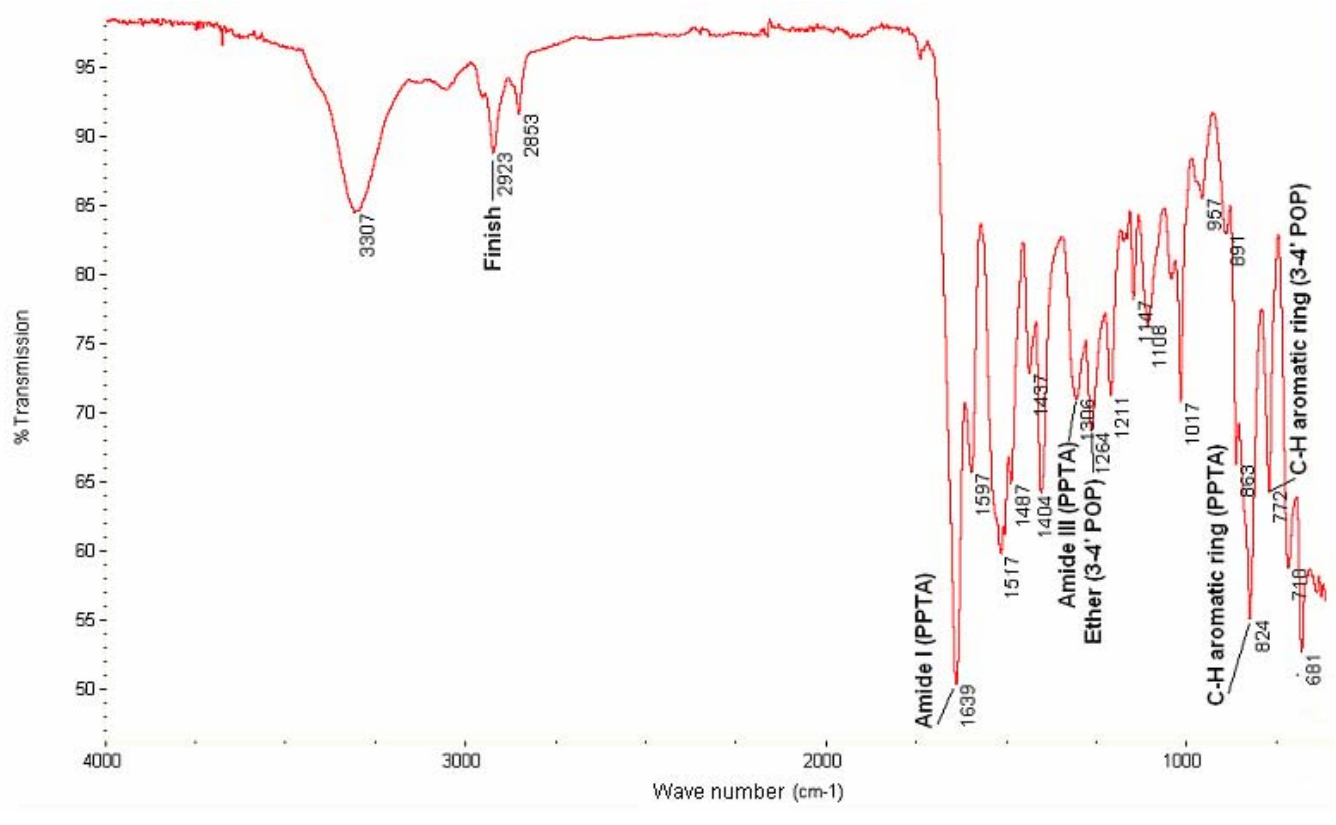

Figure 4: FTIR spectrum of as-received Technora T240 fibres

The peaks were normalised using the peak located at $\sim 824 \mathrm{~cm}^{-1}$ attributed to the $\mathrm{C}-\mathrm{H}$ deformation of PPTA sequence aromatic rings, for which the intensity and area appeared to be constant throughout the aging duration. By comparison between Technora T240 and Technora T000 spectra, the peak located at $\sim 2923 \mathrm{~cm}^{-1}$ has been attributed to the finish. This latter peak has been normalised using 
the peak areas, which appeared to be a more reliable method to evaluate the finish departure of Technora T240 fibres. As Technora fibres contain PPTA sequences, Technora and Twaron fibres spectra have some peaks related to the amide functions in common: the peak located at $\sim 1639 \mathrm{~cm}^{-1}$ is related to the $\mathrm{C}=\mathrm{O}$ vibration and the peak at $\sim 1306 \mathrm{~cm}^{-1}$ is related to the $\mathrm{C}-\mathrm{N}, \mathrm{N}-\mathrm{H}$ and $\mathrm{C}-\mathrm{C}$ combined vibrations. The peaks related to the amide functions of PPTA and 3-4' POP sequences are not clearly dissociated. Technora displays extra peaks due to the 3-4' POP sequences: the peak located at $\sim 1264 \mathrm{~cm}^{-1}$ is related to the $\mathrm{C}$-O vibration of the ether function, and the peak at $\sim 770 \mathrm{~cm}^{-1}$ is related to $\mathrm{C}-\mathrm{H}$ deformation of meta-substituted aromatic rings. ${ }^{19}$

Table 2 groups the normalised intensity of the peaks related to the finish and to the amide functions (amide I) for Technora T240 and Technora T000 fibres after one year aging at pH11 and $\mathrm{pH} 9$.

Table 2: Normalised intensity/area of the peaks related to the amide I and finish of Technora T000 and Technora T240 fibres as-received and after one year

\begin{tabular}{|c|c|c|c|c|}
\hline & \multirow{2}{*}{$\begin{array}{c}\begin{array}{c}\text { Technora T000 } \\
\text { (0 wt\% of finish) }\end{array} \\
\text { Amide I (\%) }\end{array}$} & \multicolumn{2}{|c|}{$\begin{array}{c}\text { Technora T240 } \\
\text { (2.5 wt\% of finish) }\end{array}$} \\
\hline & & & Amide I (\%) & Finish (\%) \\
\hline \multicolumn{2}{|c|}{ As-received } & $100 \pm 1.1$ & $100 \pm 0.4$ & $100 \pm 32.7$ \\
\hline \multirow[t]{2}{*}{$\mathrm{pH} 11$} & $80^{\circ} \mathrm{C}$ & $87.8 \pm 0.4$ & $97.2 \pm 1.6$ & $17.6 \pm 4.9$ \\
\hline & $20^{\circ} \mathrm{C}$ & $97.8 \pm 1.3$ & $98.9 \pm 1.2$ & $6.7 \pm 1.2$ \\
\hline \multirow[t]{2}{*}{$\mathrm{pH} 9$} & $80^{\circ} \mathrm{C}$ & $94.6 \pm 0.9$ & $95.5 \pm 0.2$ & $16.1 \pm 2.3$ \\
\hline & $20^{\circ} \mathrm{C}$ & $97.3 \pm 2.3$ & $99.1 \pm 0.6$ & $12.7 \pm 5.9$ \\
\hline
\end{tabular}

These results indicate important finish removal for all the conditions. At $\mathrm{pH} 11$, it appears that the finish departure is influenced by the temperature: the higher the temperature, the lower the finish loss. This may be explained by a cross-linking of the finish accelerated at the higher temperature. At pH9, the temperature dependence on the finish loss is not obvious within the accuracy of measurements. However, it may be concluded that the finish removal is of the same order in all the conditions considered here. As for the chains degradation, the decrease in the peak related to amide functions depends on the temperature and on the $\mathrm{pH}$ : this decrease is especially marked at $\mathrm{pH} 11$ and $80^{\circ} \mathrm{C}$ for Technora T000 fibres. At pH11 and $80^{\circ} \mathrm{C}$, the presence of finish would thus limit the degradation of amide functions by forming a "protective layer" towards surface hydrolysis. For the other conditions, the presence of finish has little influence on the surface degradation.

\section{Influence of the finish on the bulk degradation}

After evaluating the influence of the finish on the surface hydrolysis of Twaron and Technora fibres, its influence on the bulk degradation has been studied by viscosimetry.

\section{Twaron fibres}

By comparing Twaron 1000 and Twaron 1010 as-received fibres, it appears that the finish content does not have any significant influence on the reduced viscosity. Indeed, the reduced viscosity is $1105 \mathrm{~mL} / \mathrm{g}$ for Twaron 1000 fibres and $1150 \mathrm{~mL} / \mathrm{g}$ for Twaron 1010 fibres. The weight average molecular mass is not significantly affected by the finish content: $M_{w}$ is $32,100 \mathrm{~g} / \mathrm{mol}$ for Twaron 1000 fibres, $32,200 \mathrm{~g} / \mathrm{mol}$ for Twaron 1010 fibres. Although, as the reduced viscosity at $2 \times 10^{-3} \mathrm{~g} / \mathrm{mL}$ does not involve any extrapolation to be calculated, it is a more precise indicator to highlight low degradation rate. It will be chosen in the following discussion. 
Figure 5 displays the reduced viscosity at $2 \times 10^{-3} \mathrm{~g} / \mathrm{mL}$ of Twaron 1000 and Twaron 1010 fibres aged at $\mathrm{pH} 11$ and $\mathrm{pH}$. From a series of three experiments, the precision of the reduced viscosity at $2 \times 10^{-3} \mathrm{~g} / \mathrm{mL}$ has been estimated at $\pm 20 \mathrm{~mL} / \mathrm{g}$ for the Twaron 1000 as-received fibres, and at \pm 15 $\mathrm{mL} / \mathrm{g}$ for the Twaron 1010 as-received fibres.

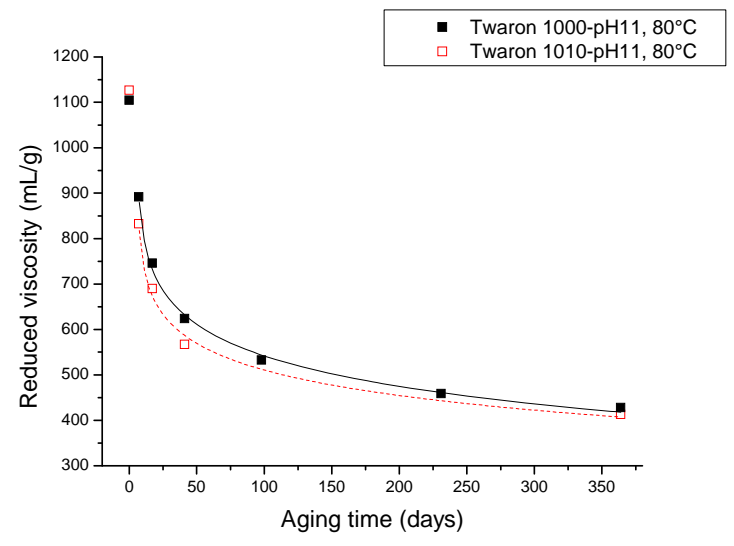

(a)

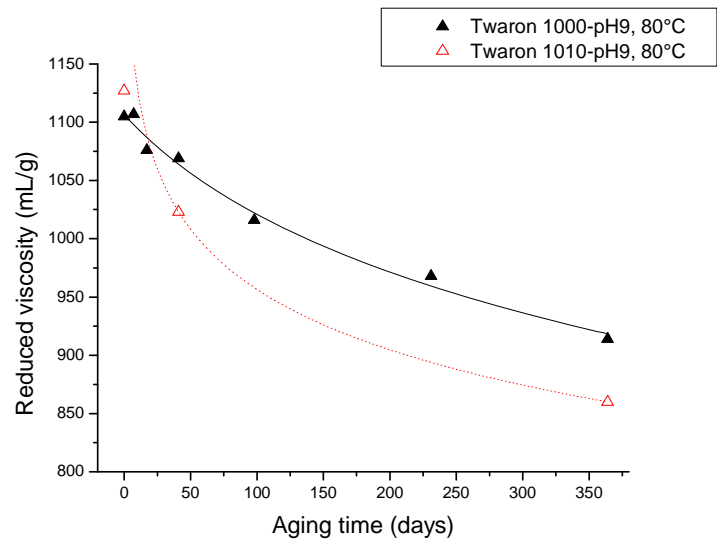

(b)

Figure 5: Evolution of the reduced viscosity at $2 \times 10^{-3} \mathrm{~g} / \mathrm{mL}$ for Twaron fibres aged (a) at pH11 and (b) at $\mathrm{pH} 9$

At $\mathrm{pH} 11$, the reduced viscosity of Twaron 1000 and Twaron 1010 fibres display the same logarithmic evolution (Figure 5 (a)). At pH9, the reduced viscosity also follows a logarithmic evolution with time, and the degradation appears to be slightly larger for Twaron 1010 fibres (Figure 5 (b)).

The logarithmic evolutions observed here have been previously interpreted as the result of two degradation processes at $\mathrm{pH} 11$, namely the destruction of the tie-molecules/fibrils and the degradation of the crystallites, and one degradation process at $\mathrm{pH} 9$, namely the destruction of the tiemolecules/fibrils only. ${ }^{20}$ The results reveal that the finish content may not change the degradation mechanisms: the degradation curves of Twaron 1010 fibres seem to conserve a logarithmic relation with time. Moreover, it appears that the higher the initial finish content, the lower the degradation rate. The finish may thus act as a "protective layer" that limits the diffusion of the solution into the fibre, lowering the bulk degradation.

\section{Technora fibres}

As for Twaron fibres, viscosity measurements of Technora fibres aim at highlighting chain scissions occurring during aging. Table 3 groups the reduced viscosity of Technora fibres with or in the absence of finish treatment. From a series of three experiments, the precision of the reduced viscosity has been estimated at $\pm 60 \mathrm{~mL} / \mathrm{g}$ for the Technora T240 as-received fibres, and at \pm 30 $\mathrm{mL} / \mathrm{g}$ for the Technora T000 as-received fibres.

Table 3: Reduced viscosity of Technora T000 and Technora T240 fibres, as-received and after one year aging, expressed in $\mathrm{mL} / \mathrm{g}$

\begin{tabular}{|l|c|c|}
\cline { 2 - 3 } \multicolumn{1}{c|}{} & $\begin{array}{c}\text { Technora T000 } \\
\text { (0 wt\% of finish) }\end{array}$ & $\begin{array}{c}\text { Technora T240 } \\
\text { (2.5 wt\% of finish) }\end{array}$ \\
\hline As-received & $498^{\circ} \mathrm{C}$ & $441^{\circ} \mathrm{C}$ \\
\hline $\mathrm{pH} 11,80^{\circ} \mathrm{C}$ & $469^{\circ} \mathrm{C}$ & $497^{\circ} \mathrm{C}$ \\
\hline $\mathrm{pH} 9,80^{\circ} \mathrm{C}$ & $466^{\circ} \mathrm{C}$ & $450^{\circ} \mathrm{C}$ \\
\hline
\end{tabular}

By comparing Technora T240 and Technora T000 as-received fibres, it appears that the presence of 
finish lowers the reduced viscosity significantly. The finish used for these fibres may thus be a low molecular mass compound that reduces the global reduced viscosity.

For Technora TOOO fibres, the reduced viscosity decreases significantly: chain scission does therefore occur under these conditions. The decrease is similar at $\mathrm{pH} 9$ and $\mathrm{pH} 11$, indicating that the $\mathrm{pH}$ has no significant influence on the bulk degradation.

For Technora T240 fibres, the reduced viscosity evolution may result from a combination between finish removal, leading to an increase in the reduced viscosity, and chain scissions, leading to a decrease in the reduced viscosity. The global increase in the reduced viscosity observed both at $\mathrm{pH} 9$ and $\mathrm{pH} 11$ must result from predominant finish departure. These results do not allow chain scissions phenomena to be highlighted, but this does not mean than they do not occur. Thermogravimetry analyses have been performed to give complementary information.

\section{Influence on the thermal characteristics}

An example of a thermogravimetric curve together with the derived thermogravimetric curve is given on Figure 6 for Twaron 1000 as-received fibres.

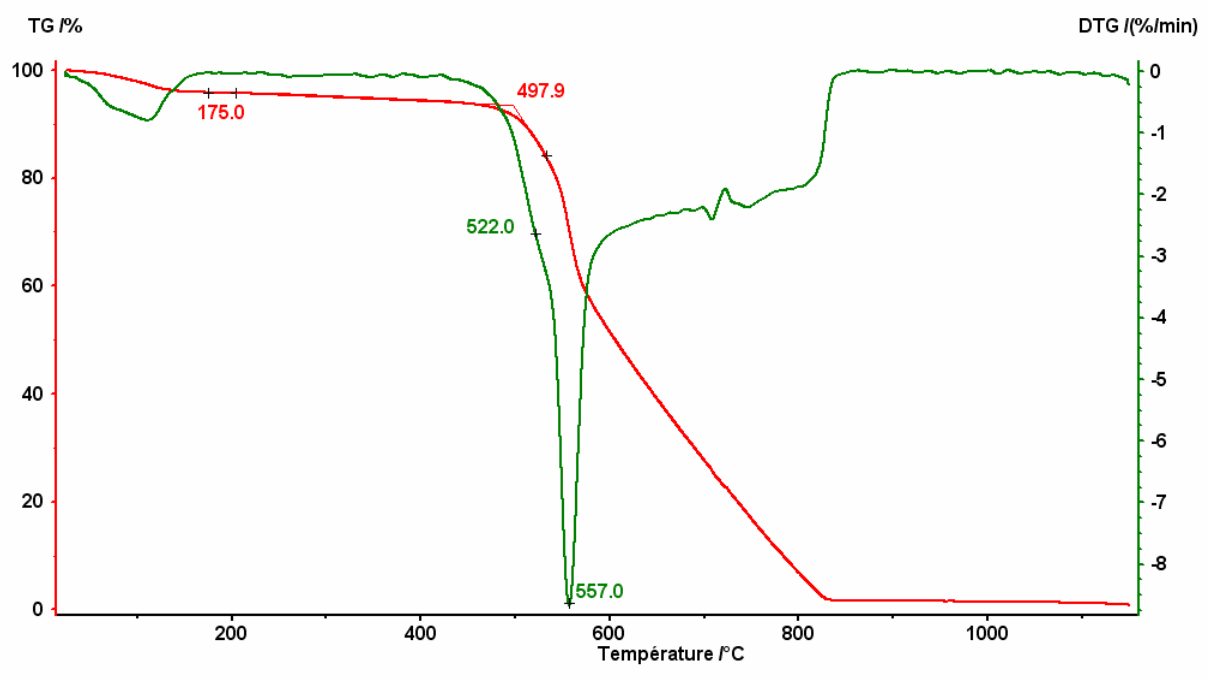

Figure 6: Thermogravimetric and derived thermogravimetric curves of Twaron 1000 fibres at $10^{\circ} \mathrm{C} /$ min under synthetic air atmosphere

The first weight loss up to $175^{\circ} \mathrm{C}$ depends on the storage conditions. It is thus attributed to the sorbed water departure. From $175^{\circ} \mathrm{C}$ to the decomposition, the weight loss is assigned to the finish decomposition. Finally, the beginning of the most important weight loss at $498^{\circ} \mathrm{C}$ was identified as the onset decomposition temperature of the PPTA itself.

In a similar way, for as-received Technora T240 fibres, the sorbed water removal is located between ambient temperature and $140^{\circ} \mathrm{C}$, the residual finish content between $140^{\circ} \mathrm{C}$ and the decomposition temperature.

\section{Twaron fibres}

Table 4 groups the decomposition temperature of Twaron fibres measured by TGA. From a series of five experiments, the precision of the decomposition temperature measurement has been estimated at $\pm 4^{\circ} \mathrm{C}$.

Table 4: Decomposition temperatures of Twaron fibres as received and after one year aging 


\begin{tabular}{|c|c|c|}
\cline { 2 - 3 } \multicolumn{1}{c|}{} & $\begin{array}{c}\text { Twaron 1010 } \\
\text { (0.14 wt\% of finish) }\end{array}$ & $\begin{array}{c}\text { Twaron } 1000 \\
(0.6-1 \text { wt } \% \text { of finish })\end{array}$ \\
\hline As-received & $495^{\circ} \mathrm{C}$ & $498^{\circ} \mathrm{C}$ \\
\hline $\mathrm{pH} 11,80^{\circ} \mathrm{C}$ & $473^{\circ} \mathrm{C}$ & $479^{\circ} \mathrm{C}$ \\
\hline $\mathrm{pH} 9,80^{\circ} \mathrm{C}$ & $489^{\circ} \mathrm{C}$ & $496^{\circ} \mathrm{C}$ \\
\hline
\end{tabular}

It appears that the decomposition temperature of Twaron 1000 and Twaron 1010 as-received fibres are close: the finish content has little influence on the decomposition temperature of as-received fibres. The decomposition temperature decreases after one year at $\mathrm{pH} 11$ and $80^{\circ} \mathrm{C}$ for both kinds of Twaron, but slightly more for Twaron 1010 fibres. In a similar way, after one year at $\mathrm{pH} 9$ and $80^{\circ} \mathrm{C}$, the decomposition temperature decreases for Twaron 1010 fibres, whereas it remains unchanged for Twaron 1000 fibres. It appears thus that the higher the initial finish content, the less the decomposition temperature of hydrolytically-aged Twaron fibres decreases.

By analogy with viscosity measurements, it can be noted that the decomposition temperature globally decreases with reduced viscosity. Indeed, it is likely that low molecular weight chains decompose at lower temperature. From this assumption, it appears that the finish content of Twaron fibres has a slight influence on the hydrolytic degradation: the lower the initial finish content, the lower the decomposition temperature, and thus the larger the chain degradation rate. As mentioned in the previous section, the finish may thus act as a protective layer which limits hydrolytic degradation. Thermogravimetric analysis could thus prove to be a complementary technique to viscosity measurements to reveal chain degradations.

\section{Technora fibres}

Table 5 groups the decomposition temperatures of Technora fibres measured by TGA. From a series of tests on six samples, the precision of the decomposition temperature measurement has been estimated at $\pm 4^{\circ} \mathrm{C}$.

Table 5: Decomposition temperatures of Technora fibres as-received and after one year aging

\begin{tabular}{|c|c|c|}
\cline { 2 - 3 } \multicolumn{1}{c|}{} & $\begin{array}{c}\text { Technora T000 } \\
\text { (0 wt\% of finish) }\end{array}$ & $\begin{array}{c}\text { Technora T240 } \\
(2.5 \mathrm{wt} \% \text { of finish })\end{array}$ \\
\hline As-received & $474^{\circ} \mathrm{C}$ & $472^{\circ} \mathrm{C}$ \\
\hline $\mathrm{pH} 11,80^{\circ} \mathrm{C}$ & $452^{\circ} \mathrm{C}$ & $463^{\circ} \mathrm{C}$ \\
\hline $\mathrm{pH} 9,80^{\circ} \mathrm{C}$ & $457^{\circ} \mathrm{C}$ & $462^{\circ} \mathrm{C}$ \\
\hline
\end{tabular}

It appears that the decomposition temperature of Technora T240 and Technora T000 as-received fibres are similar: the presence of finish has little influence on the decomposition temperature. After one year at $\mathrm{pH} 11$ and at $\mathrm{pH} 9$ at $80^{\circ} \mathrm{C}$, this temperature decreases for both kind of Technora fibres. The decrease is slightly larger for Technora TOOO fibres for all the conditions. The presence of finish limits the decomposition temperature decrease.

By analogy with viscosity measurements, it can be noted that the decomposition temperature of Technora TOOO fibres decreases with the reduced viscosity. As for Twaron fibres, it would be likely that low molecular weight chains decompose at lower temperature. As the decomposition temperature is lower for Technora TOOO for all the aging conditions, it can be concluded that the degradation of Technora fibres is larger without finish treatment. The finish may thus act as a protective layer which limits hydrolytic degradation. As TGA permit to reveal chain degradations for Technora fibres, it could be considered as a complementary technique to viscosimetry. The evolution of the reduced viscosity observed previously for Technora T240 fibres do thus come from a combination between chain degradations and finish removal. 


\section{Influence of the finish on the surface state}

\section{Twaron fibres}

Figures 7 and 8 group the SEM observations of Twaron fibres aged under different basic conditions.

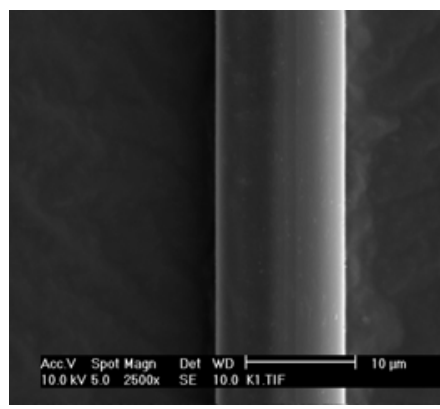

(a)

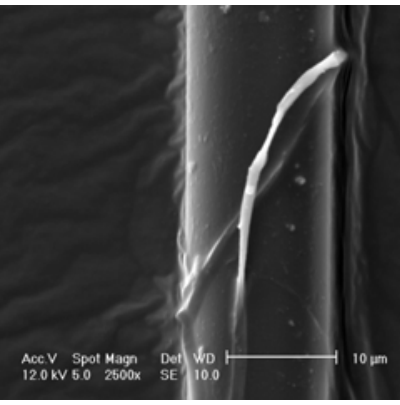

(b)

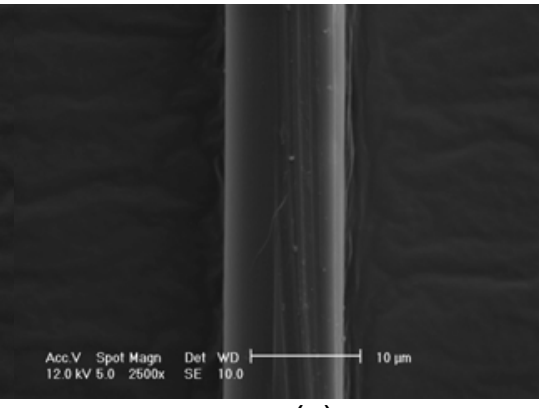

(c)

Figure 7: SEM observations in SE mode of Twaron 1010 fibres (a) as-received, (b) after one year at $\mathrm{pH} 11$ and $80^{\circ} \mathrm{C}$, and (c) after one year at $\mathrm{pH} 9$ and $80^{\circ} \mathrm{C}$

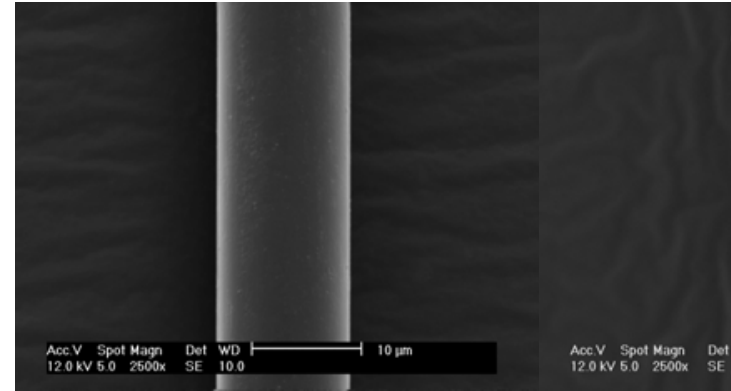

(a)

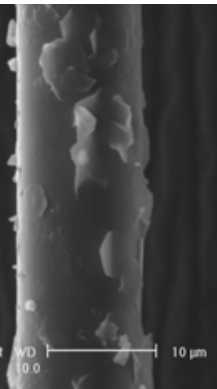

(b)

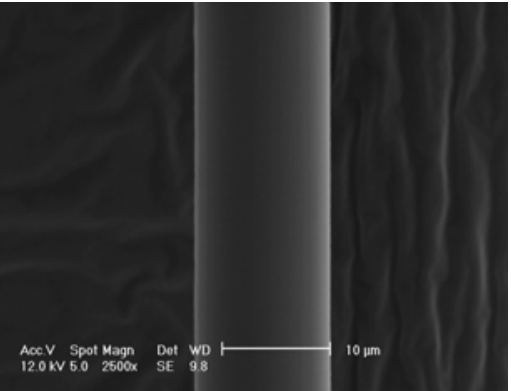

(c)

Figure 8: SEM observations in SE mode of Twaron 1010 fibres (a) as-received, (b) after one year at $\mathrm{pH} 11$ and $80^{\circ} \mathrm{C}$, and (c) after one year at $\mathrm{pH} 9$ and $80^{\circ} \mathrm{C}$

It must be noted that there is no significant evolution of the diameter of Twaron fibres over the aging period considered here: whatever the aging condition, it remains between $\sim 11.5$ and $12.2 \mu \mathrm{m}$.

The surfaces of Twaron 1000 and Twaron 1010 as-received fibres do not display any defects. After one year at $\mathrm{pH} 9$ and $\mathrm{pH} 11$, the fibres with lower finish content globally display more fibril departure resulting in more longitudinal grooves at the surface. These defects may be attributed to abrasion probably due to the stirring of the solutions. It appears thus that the resistance to abrasion is improved with higher finish content. After one year at $\mathrm{pH} 11$ and $80^{\circ} \mathrm{C}$, Twaron 1000 fibres present some excoriated layers (some of them seem hexagonal), which may be due to rearrangement of some drawing agent embedded in the surface.

\section{Technora fibres}

Figures 9 and 10 group the SEM observations of Technora fibres. 


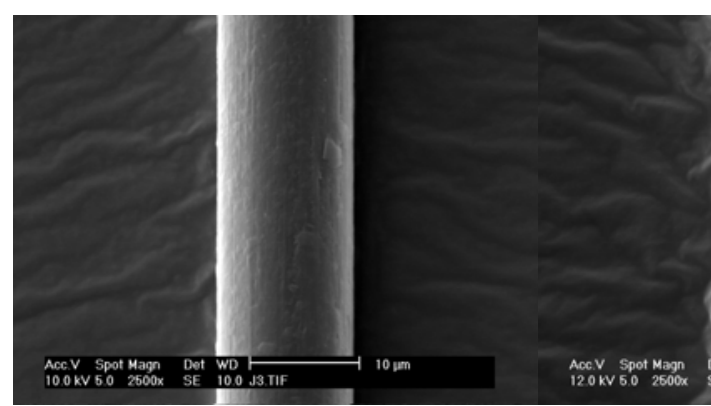

(a)

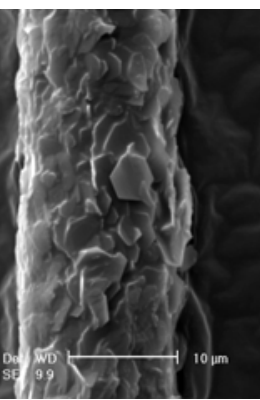

(b)

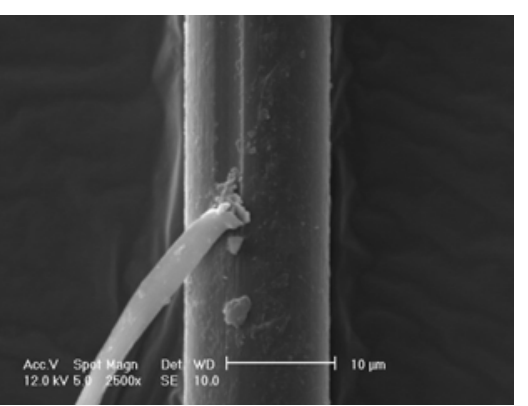

(c)

Figure 9: SEM observations in SE mode of Technora T000 fibres (a) as-received, (b) after one year at $\mathrm{pH} 11$ and $80^{\circ} \mathrm{C}$, and (c) after one year at $\mathrm{pH} 9$ and $80^{\circ} \mathrm{C}$

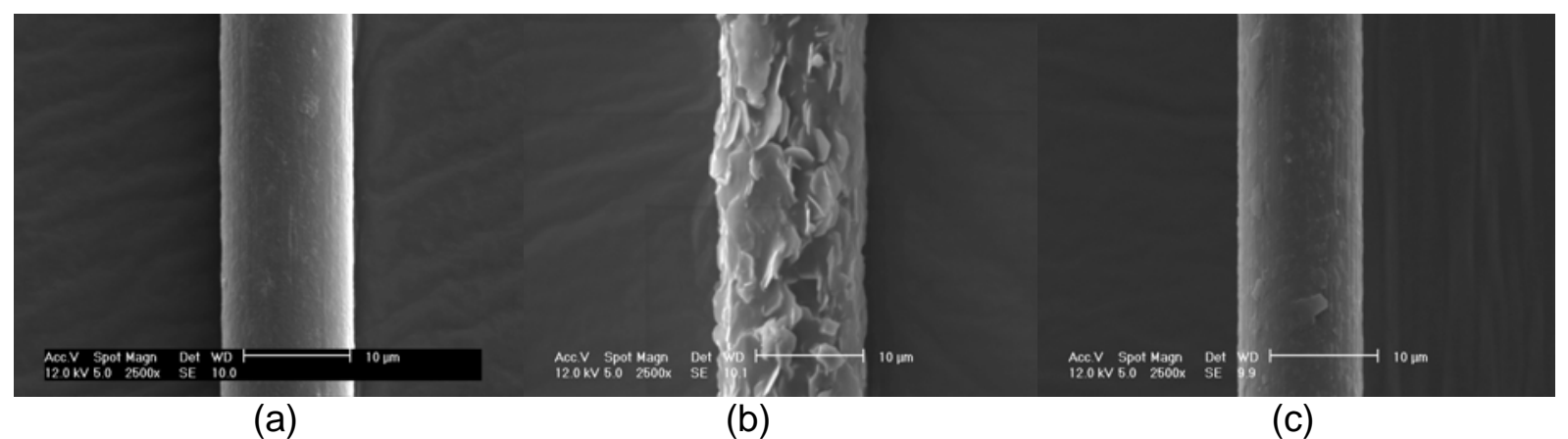

(a)

(b)

(c)

Figure 10: SEM observations in SE mode of Technora T240 fibres (a) as-received, (b) after one year at $\mathrm{pH} 11$ and $80^{\circ} \mathrm{C}$, and (c) after one year at $\mathrm{pH} 9$ and $80^{\circ} \mathrm{C}$

The fibres diameter has been measured using the laser micrometer and by SEM. There is again no significant evolution of the diameter of Technora fibres over the aging period considered here: whatever the aging condition, it remains between $\sim 11.5$ and $12.4 \mu \mathrm{m}$. The surfaces of Technora T240 and Technora TOOO as-received fibres do not display any defects. After one year at $\mathrm{pH} 9$ and $80^{\circ} \mathrm{C}$, the fibre without finish globally displays more fibril removal than Technora T240, resulting in more longitudinal grooves at the surface. As for Twaron fibres, these defects may be attributed to abrasion probably due to the stirring of the solutions. It appears thus that the resistance to abrasion is improved with higher finish content. After one year at $\mathrm{pH} 11$ and $80^{\circ} \mathrm{C}$, Technora T000 and Technora T240 fibres both display some excoriated layers (some of them seem hexagonal), which may be due to rearrangement of some drawing agent embedded in the surface.

\section{Influence on the mechanical properties}

After evaluating the changes in chemical, thermal and morphological characteristics of hydrolyticallyaged aramid fibres, it is interesting to investigate how they affect the functional properties. Tensile tests were therefore carried out to identify the changes responsible for mechanical property evolutions. To avoid any error due to the slight differences measured in diameters, the tensile properties have been expressed in Newton and then normalised with respect to the initial value. Thereby, the slope of the force-strain curves does not provide the tensile modulus but is representative of the residual stiffness of the fibres.

\section{Twaron fibres}

Figure 11 groups the tensile strength changes of Twaron 1000 and Twaron 1010 fibres aged at pH11 and $\mathrm{pH} 9$. 

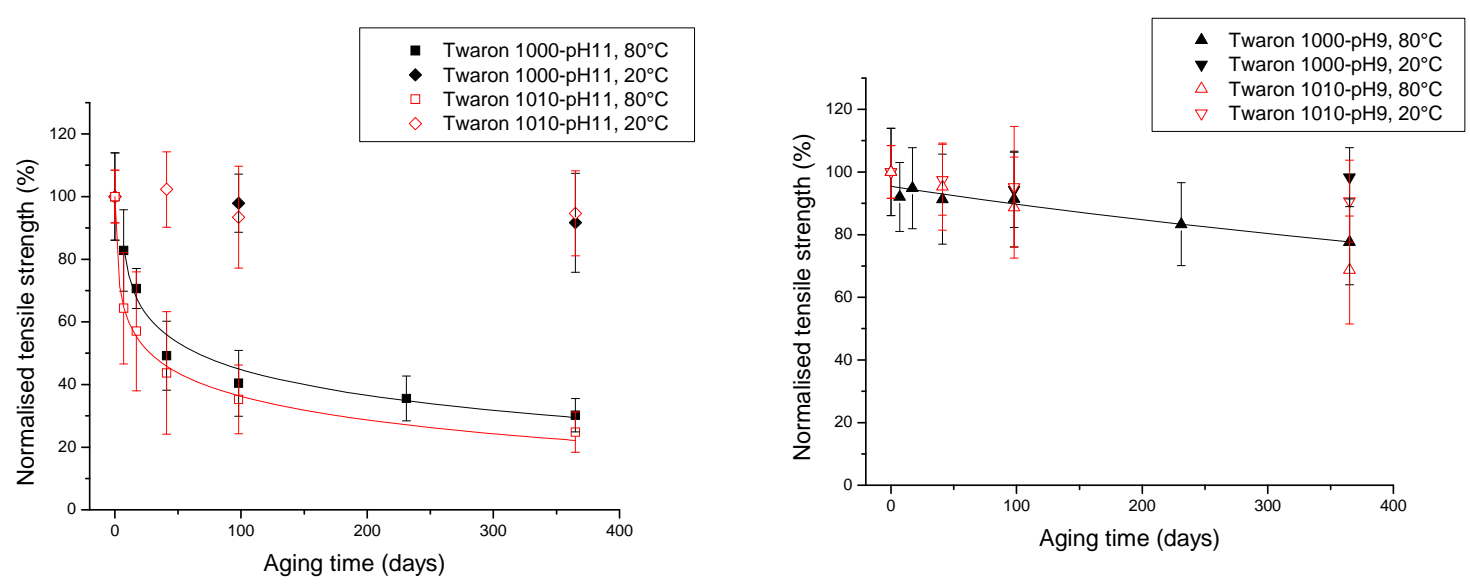

Figure 11: Evolution of the tensile strength of Twaron fibres aged at $\mathrm{pH} 11$ and $\mathrm{pH} 9$

It appears that the tensile strength drop is larger at $\mathrm{pH} 11$ than at $\mathrm{pH} 9$ and larger at $80^{\circ} \mathrm{C}$ than at $20^{\circ} \mathrm{C}$. At $\mathrm{pH} 11$ and $20^{\circ} \mathrm{C}$, there is no influence of the finish content on the tensile strength degradation rate. In the other conditions, there is only a slight influence of the finish content on the tensile strength evolution: the strength degradation is slightly higher with a lower initial finish content.

At $\mathrm{pH} 11$ and $80^{\circ} \mathrm{C}$, it appears that the degradation is accelerated at the beginning of aging in the absence of finish, but the degradation rates reach a similar value at longer aging times. Consequently, the higher the finish content, the more the fibres are "protected" towards tensile strength degradations. This may be attributed to the lower bulk degradation and less surface damage observed for the fibres with higher finish content.

Table 6 presents the residual tensile modulus of Twaron fibres after one year aging at pH11 and pH9.

The tensile modulus does not vary significantly over the aging time considered here. Whatever the aging conditions, the finish content does not have any significant influence on the tensile modulus: its value levels off throughout aging. As explained previously, ${ }^{20}$ the structural changes induced by aging at $\mathrm{pH} 9$ and $\mathrm{pH} 11$ affect the tensile strength but not the tensile modulus.

\section{Technora fibres}

Figure 12 groups the tensile strength evolutions of Technora T240 and Technora T000 fibres aged at $\mathrm{pH} 11$ and $\mathrm{pH} 9$.
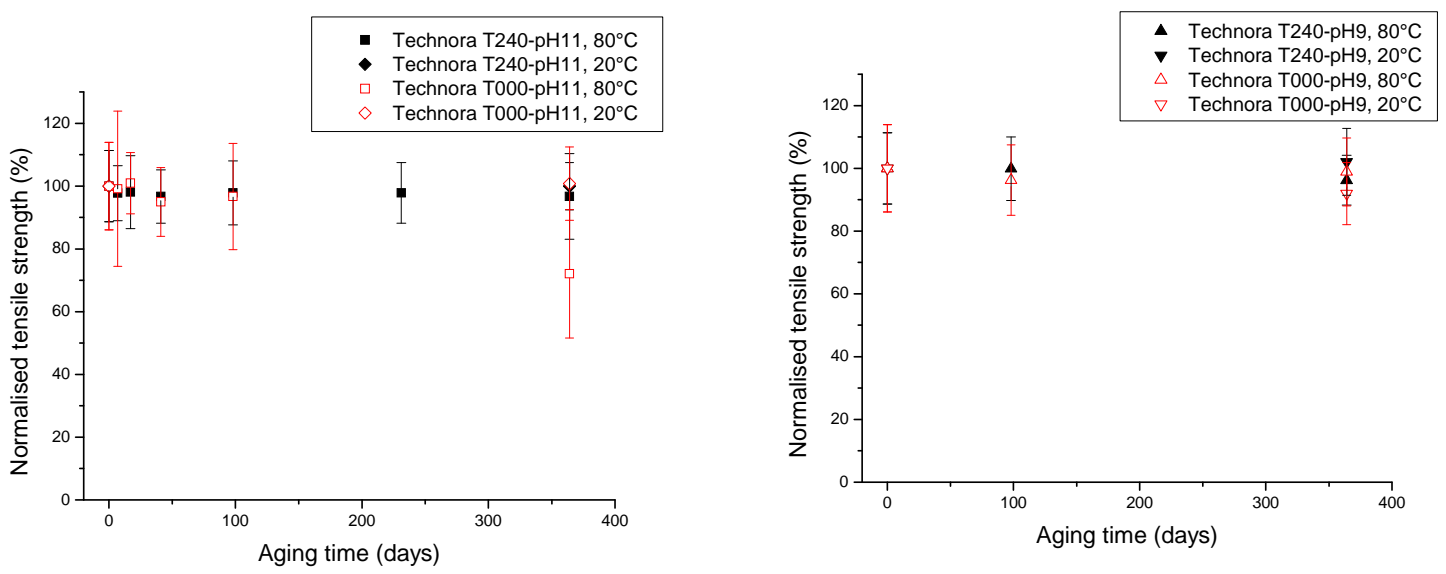

Figure 12: Evolution of the tensile strength of Technora fibres aged at $\mathrm{pH} 11$ and $\mathrm{pH} 9$ 
The decrease in the tensile strength is not significant under any conditions, except at $\mathrm{pH} 11$ and $80^{\circ} \mathrm{C}$ for the Technora TOOO fibres where the decrease reaches almost 30\%. Consequently, the presence of finish protects the fibres towards tensile strength degradations occurring at $\mathrm{pH} 11$ and $80^{\circ} \mathrm{C}$. At $\mathrm{pH} 9$, the tensile strength is not affected by the presence of finish, even though slightly higher bulk degradation and more surface damage have been observed for the Technora T000. At pH11 and $80^{\circ} \mathrm{C}$, the higher surface degradation rate of Technora TOOO fibres may explain the larger tensile strength decrease. The surface degradation of Technora fibres would thus govern the tensile strength conservation.

The high stability of Technora fibres in water and in moderately alkaline conditions has been reported elsewhere. ${ }^{21}$ Imuro and Yoshida ${ }^{6}$ postulated that the superior chemical-resistance of Technora arises from the total effect of (a) the dilution of aramid linkage by less chemical-reactive ether-linkage, (b) the high orientation of the amorphous part, which prevents water and chemical agent from penetrating into the fibre, and (c) its dense structure.

Table 7 presents the residual tensile modulus of Technora fibres after one year aging at $\mathrm{pH} 11$ and pH9.

Table 7: Residual stiffness of Technora T000 and Technora T240 after one year aging at pH11 and pH9

\begin{tabular}{|c|c|c|c|}
\cline { 2 - 3 } \multicolumn{1}{c|}{} & $\begin{array}{c}\text { Technora T000 } \\
\text { (0 wt\% of finish) }\end{array}$ & $\begin{array}{c}\text { Technora T240 } \\
\text { (2.5 wt\% of finish) }\end{array}$ \\
\hline \multicolumn{2}{c|}{ As-received } & $100 \pm 9 \%$ & $100 \pm 8 \%$ \\
\hline \multirow{2}{*}{$\mathrm{pH} 11$} & $80^{\circ} \mathrm{C}$ & $100 \pm 8 \%$ & $102 \pm 7 \%$ \\
\cline { 2 - 4 } & $20^{\circ} \mathrm{C}$ & $99 \pm 6 \%$ & $98 \pm 7 \%$ \\
\hline \multirow{2}{*}{$\mathrm{pH} 9$} & $80^{\circ} \mathrm{C}$ & $100 \pm 8 \%$ & $97 \pm 5 \%$ \\
\cline { 2 - 4 } & $20^{\circ} \mathrm{C}$ & $92 \pm 10 \%$ & $103 \pm 9 \%$ \\
\hline
\end{tabular}

Once again, the tensile modulus does not vary significantly over the aging time considered here. ${ }^{21}$

\section{Conclusions}

The influence of the finish on the durability of Twaron and Technora fibres under an alkaline environment has been evaluated by FTIR, viscosity measurements, TGA and tensile tests. Several conclusions may be proposed:

- $\quad$ Finish departure has been revealed under exposure to basic conditions.

For Twaron fibres, higher finish content appears to reduce the tensile strength degradation. The finish may act as a barrier that slightly limits bulk hydrolytic degradation, and improves the resistance to abrasion. For all the conditions, the finish content does not affect the modulus.

For Technora fibres, the presence of finish appears to reduce the tensile strength degradation at $\mathrm{pH} 11$ and $80^{\circ} \mathrm{C}$ only. For these conditions, the finish may act as a barrier that limits bulk and surface hydrolytic degradation, and improves the resistance to abrasion. Even though the bulk degradation and abrasion are also limited at $\mathrm{pH} 9$ and $80^{\circ} \mathrm{C}$ with higher finish content, the tensile strength conservation is not improved. The surface degradation is thus a serious concern for tensile strength conservation in an alkaline environment. For all the conditions, the finish content does not affect the tensile modulus.

The finish content is shown to have some influence on the aramid fibres durability. The life-time of aramid geotextiles may be improved by application of a non-soluble finish treatment.

The authors are grateful to Otto Grabandt and Bertil van Berkel of Teijin Aramid for the fibre samples and their cooperation. The strong commitment of Nicolas Barberis, Dominique Duragrin (LCPC Paris) 
and Nicolas Lacotte (IFREMER Brest) to the aging and characterisation studies presented here is also much appreciated.

\section{References}

1. Benneton J-P, Blivet J-C, Perrier H. in Proceedings of the Rencontres GéotextilesGéomembranes, 1997: 58-62.

2. Auray G, Simons D. JEC Composites Magazine 2007, 35: 58-61.

3. Blivet J-C, Garcin P, Hirschauer A, Nancey A, Villard P. in Proceedings of the Rencontres Géosynthétiques 2006: 281-288.

4. Auerbach I. Journal of Applied Polymer Science 1989, 37: 2213-2227.

5. Morgan RJ, Pruneda CO, Butler N, Kong F-M, Caley L, Moore RL. in Proceedings of the $29^{\text {th }}$ National SAMPE Symposium, 1984: 891-900.

6. Imuro $\mathrm{H}$, Yoshida $\mathrm{N}$. in Proceedings of the $25^{\text {th }}$ International Man Made Fibres Congress, 1986: 1-23.

7. Springer H, Abu Obaid A, Prabawa AB, Hinrichsen G. Textile Research Journal 1998, 68(8): 588-594.

8. $\quad$ Slade PE. Handbook of Fiber Finish Technology; Marcel Dekker, INC, 1998.

9. Moraes D'Almeida JR, Hearn D, Bunsell AR. Polymer Engineering and Science 1984, 24(1): 42-47.

10. Wagner JR, Ahles LJ. in Proceedings of the Nonwovens Conference, Tappi Press, 1987: 197203.

11. Arpin M, Strazielle C. Polymer 1977, 18(6): 591-598.

12. Aoki $\mathrm{H}$, Onogi $\mathrm{Y}$, White JL, Fellers JF. in Proceedings of the $37^{\text {th }}$ Annual Technical Conference Society of Plastics Engineers, 1979: 642-645.

13. Ozawa S. Polymer Journal 1987, 19(1): 119-125.

14. Bunsell AR. Journal of Materials Science 1975, 10: 1300-1308.

15. Allen SR, Roche EJ. Polymer 1989, 30: 996-1003.

16. Penn L, Larsen F. Journal of Applied Polymer Science 1979, 23: 59-73

17. Park S-J, Seo M-K, Ma T-J, Lee D-R. Journal of Colloid and Interface Science 2002, 252, 249255.

18. Zhang H, Zhang J, Chen J, Hao X, Wang S, Feng X, Guo Y. Polymer Degradation and Stability 2006, 91: 2761-2767.

19. Ferreira M. phD thesis from Université des Sciences et Technologies de Lille 1, 1996.

20. Derombise G, Vouyovitch Van Schoors L, Davies P. To be published (b).

21. Derombise G, Vouyovitch Van Schoors L, Davies P. To be published (a). 